\title{
IDENTIFIKASI SEMPADAN SUNGAI WAI RUHU TERDAMPAK GENANGAN, BERDASAR ANALISA DEBIT BANJIR RENCANA $(Q)$ METODE RASIONAL MODIFIKASI KALA ULANG 2, 5, 10, 50 TAHUN
}

\author{
Steanly R.R.Pattiselanno \\ Jurusan Teknik Sipil, Politeknik Negeri Ambon \\ steanly.r.r.pattiselanno@gmail.com
}

\begin{abstract}
Land needs for residential areas make the tendency of the edge of the city whose land is located on hill slopes to be converted into residential land.As a result, the green area is reduced which impacts on the loss of the water catchment area in the watershed which makes the threat of lack of future water sources, as well as the threat of flooding that can occur at any time as the effects of burdens on the slopes are increasing. The Wai Ruhu watershed is one of the degraded areas due to the conversion of catchment land to residential areas. Spatial planning that tends to follow a needs approach without regard to the conservation of land and water in a watershed, will significantly result in a loss of water that functions for natural recharge, decreasing river quality and loss of life of aquatic ecosystems. To analyze the problem of runoff impacts on the Wai Ruhu watershed, a study of modifying of the rational method with the duration of 2, 5, 10 and 50 years was used with GIS. The results showed that the planned flood cumulative discharge with the lowest value occurred in tributaries in the $7^{\text {th }}$ subbassin, valid for a 2-year return period $=0.352 \mathrm{~m}^{3} / \mathrm{sec}, 5$-year period $=0.502 \mathrm{~m}^{3} / \mathrm{det}$, 10 -year period $=0.579$ $\mathrm{m}^{3} / \mathrm{sec}$ and 50 years period $=0.716 \mathrm{~m}^{3} / \mathrm{sec}$. While the planned cumulative flood discharge with the highest value occurs in tributaries in the $17^{\text {th }}$ subbassin, and is valid for return period 2; 5; 10 and 50 years, which are 21,057; 29,$937 ; 34,590 ; 42,730 \mathrm{~m}^{3} / \mathrm{sec}$. Runoff on each tributary in the Wai Ruhu watershed with minimum height (no runoff) occurs in each tributary in the second, fourth, fifth, $7^{\text {th }}, 10^{\text {th }}, 11^{\text {th }}, 13^{\text {th }}, 15^{\text {th }}$ and $16^{\text {th }}$, for a 2 -year return period because it is the river that supply the initial flood discharge to other tributaries, while the maximum height occurs in tributaries in the $6^{\text {th }}$ subbassin, which is $4,8009 \mathrm{~m}$ from normal river water levels. The minimum width of runoff occurs in the same subbassin with the minimum height, while the maximum width occurs in tributaries in the $12^{\text {th }}$ sub-watershed, which is as wide as $60.2991 \mathrm{~m}$ from the river bank.
\end{abstract}

\begin{abstract}
ABSTRAK
Kebutuhan lahan untuk tempat tinggal menjadikan kecenderungan tepi kota yang lahannya berada di lerenglereng bukit dikonversi untuk menjadi lahan pemukiman. Akibatnya area hijau menjadi berkurang yang berimbas pada kehilangan area tangkapan air pada DAS yang menjadikan ancaman kekurangan sumber air kedepan, serta ancaman banjir yang bisa terjadi sewaktu-waktu sebagai efek beban pada lereng yang semakin bertambah. DAS Wai Ruhu termasuk salah satu kawasan yang terdegradasi akibat konversi lahan tangkapan menjadi pemukiman warga. Penataan ruang yang cenderung mengikuti pendekatan kebutuhan tanpa memperhatikan aspek konservasi tanah dan air di sebuah DAS, secara signifikan akan mengakibatkan kehilangan banyak air yang berfungsi untuk resapan alami, penurunan kualitas sungai dan hilangnya kehidupan ekosistem air. Untuk menganalisa masalah dampak limpasan pada DAS Wai Ruhu maka digunakanlah sebuah kajian metode rasional modifikasi kala ulang durasi waktu 2, 5, 10 dan 50 tahun dengan GIS. Hasil penelitian menunjukkan bahwa debit kumulatif banjir rencana dengan nilai terendah terjadi pada anak sungai pada sub DAS ke-7, berlaku untuk periode ulang 2 tahun $=0,352 \mathrm{~m}^{3} / \mathrm{det}$, periode 5 tahun $=0,502 \mathrm{~m}^{3} / \mathrm{det}$, periode 10 tahun $=0,579 \mathrm{~m}^{3} /$ det dan periode 50 tahun $=0,716 \mathrm{~m}^{3} /$ det. Sedangkan debit kumulatif banjir rencana dengan nilai tertinggi terjadi pada anak sungai pada sub DAS ke-17, dan berlaku untuk periode ulang $2 ; 5 ; 10$ dan 50 tahun yaitu masing-masing sebesar 21,057;29,937;34,590;42,730 $\mathrm{m}^{3} /$ det. Limpasan pada masing-masing anak sungai di DAS Wai Ruhu dengan tinggi minimum (tidak ada limpasan), terjadi di masing-masing anak sungai pada sub DAS ke-2, 4, 5, 7, 10, 11, 13, 15 dan ke-16 untuk periode ulang 2 tahun karena merupakan sungai pensuplai debit banjir awal ke anak sungai lainnya, sedangkan tinggi maksimum terjadi pada anak sungai di sub DAS ke-6 yaitu sebesar 4,8009 m dari muka air sungai normal. Lebar minimum limpasan, terjadi pada sub DAS yang sama dengan tinggi minimum, sedangkan lebar maksimum terjadi pada anak sungai di sub DAS ke-12 yaitu selebar 60,2991 m dari tepi sungai.
\end{abstract}

Kata kunci: sungai Wai Ruhu; limpasan; banjir rencana; rasional modifikasi 


\section{JURNAL SIMETRIK VOL.8, NO.2, DESEMBER 2018}

\section{PENDAHULUAN}

Kota Ambon sebagai tujuan aktivitas bagi masyarakat urban di Maluku, sampai tahun 2010 memiliki catatan jumlah penduduk sebesar 331.254 jiwa, dan terus bertambah setiap tahunnnya, misalnya dari data tahun 2006 yang hanya 263.146 jiwa. Kepadatan penduduk Kota Ambon tahun 2010 adalah 921,56 jiwa/km².(Sumber:http://ambonkota.bps.go.id/ tabel-23-penduduk.html))

Kebutuhan lahan untuk tempat tinggal menjadikan kecenderungan tepi kota yang lahannya berada di lereng-lereng bukit dikonversi untuk menjadi lahan pemukiman. Akibatnya area hijau menjadi berkurang yang berimbas pada kehilangan area tangkapan air pada DAS yang menjadikan ancaman kekurangan sumber air kedepan, serta ancaman banjir dan longsor yang bisa terjadi sewaktuwaktu sebagai efek beban pada lereng yang semakin bertambah.

DAS Wai Ruhu termasuk salah satu kawasan yang terdegradasi akibat konversi lahan tangkapan menjadi pemukiman warga. Dampaknya mulai terasa terhadap debit air sungai Wai Ruhu yang semakin berkurang dari waktu ke waktu, teristimewa di musim kering dan juga banjir yang terjadi di saat musim basah/penghujan misalnya seperti pada peristiwa tanggal 1 Agustus 2012 (http://www.radarambon.co/ read-20120803233042-8-sungai-di-ambon-kritisbanjir-bisa-terulang-berita_utama).

Perubahan penggunaan lahan akan menjadi sesuatu yang serius dalam banyak wilayah DAS. Penataan ruang cenderung mengikuti pendekatan kebutuhan, yaitu direncanakan untuk memenuhi kebutuhan yang sedang berkembang. Pembangunan tanpa memperhatikan aspek konservasi tanah dan air di sebuah DAS, secara signifikan akan mengakibatkan kehilangan banyak air yang berfungsi untuk resapan alami, penurunan kualitas sungai dan hilangnya kehidupan ekosistem air.

Mencermati fenomena bencana alam yang terjadi di DAS Wai Ruhu beberapa tahun belakangan ini, maka dirasakan perlu mitigasi dan identifikasi terhadap area terpengaruh limpasan aliran sungai pada Sub-Sub DAS di DAS Wai Ruhu, sehingga dapat terpetakan suatu model area terdampak genangan pada sempadan sungai di kawasan DAS Wai Ruhu.

\section{TINJAUAN PUSTAKA}

\subsection{DAS}

DAS adalah suatu wilayah daratan yang secara topografik dibatasi oleh punggung-punggung gunung yang menampung dan meyimpan air hujan (catchment area) untuk kemudian menyalurkannya ke laut melalui sungai utama (Asdak, 2004).

\subsection{Curah Hujan Rancangan}

Curah hujan rancangan adalah curah hujan terbesar yang mungkin terjadi di suatu daerah dengan peluang tertentu.Metode analisis hujan rancangan tersebut, pemilihannya sangat bergantung dari kesesuaian parameter statistik dari data yang bersangkutan, atau dipilih berdasarkan pertimbanganpertimbangan teknis lainnya. Untuk menentukan metode yang sesuai, maka terlebih dahulu harus dihitung besarnya parameter statistik yaitu koefisien kemencengan (skewness) atau Cs, dan koefisien kepuncakan (kurtosis) atau Ck. Persamaan yang digunakan adalah (Sri Harto, 1993):

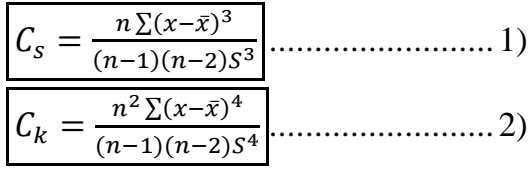

Hasil perhitungan $C_{s}$ dan $C_{k}$ tersebut kemudian disesuaikan dengan syarat pemilihan metode frekuensi seperti berikut (Tabel 1):

Tabel 1.Pemilihan Metode Frekuensi

\begin{tabular}{lcc}
\hline \multicolumn{1}{c}{ Jenis Metode } & $\mathrm{C}_{\mathrm{k}}$ & $\mathrm{C}_{\mathrm{s}}$ \\
\hline Gumbel & $<5,4002$ & 1,1396 \\
Normal & 3,0 & 0 \\
Log Person Type III & bebas & bebas \\
\hline
\end{tabular}

(Sumber: Sri Harto, 1993)

\subsection{Intensitas Hujan}

Intensitas hujan adalah tingginya curah hujan dalam periode tertentu yang dinyatakan dalam satuan $\mathrm{mm} / \mathrm{jam}$. Besarnya intensitas curah hujan berbedabeda disebabkan oleh lamanya curah hujan atau frekuensi kejadian. Rumus empiris yang dipakai untuk menghitung intensitas hujan dalam menentukan debit puncak dengan metode Rasional Modifikasi, menggunakan rumus Mononobe (Nugroho, 2012):

$$
\mathrm{I}=\frac{\mathrm{R}_{24}}{24}\left(\frac{24}{\mathrm{t}}\right)^{\mathrm{m}}
$$

dimana:

$$
\begin{aligned}
& I=\text { Intensitas hujan ( } \mathrm{mm} / \mathrm{jam}) \\
& R_{24}=\text { curah hujan maksimum } 24 \text { jam }(\mathrm{mm}) \\
& t=\text { waktu konsentrasi } \\
& m=\text { konstanta }
\end{aligned}
$$

\subsection{Waktu Konsentrasi $\left(T_{c}\right)$}

Waktu konsentrasi adalah waktu perjalanan yang diperlukan oleh air dari tempat paling jauh (hulu DAS) sampai titik pengamatan aliran air (outlet). Dalam metode Rasional Modifikasi, untuk menentukan waktu konsentrasi menggunakan rumus:

$$
T_{c}=T_{o}+T_{d} \text {. }
$$

dimana:

$\mathrm{T}_{\mathrm{c}}=$ waktu konsetntrasi (jam)

$\mathrm{T}_{\mathrm{o}}=$ Overland flow time atau waktu yang dibutuhkan limpasan (run off) untuk mengalir melalui permukaan tanah ke outlet terdekat.

$T_{o}$ dapat dihitung dengan rumus berikut, (Suripin, 2002). 


\section{JURNAL SIMETRIK VOL.8, NO.2, DESEMBER 2018}

$$
\left.T_{o}=\left[\frac{2}{3} \times 3,28 \times L \times \frac{n}{\sqrt{5}} \times \frac{1}{60}\right](j a m) \ldots \ldots . \quad 5\right)
$$

dimana:

$$
\begin{aligned}
\mathrm{L}= & \text { panjang lintasan aliran di atas permukaan } \\
& \text { lahan }(\mathrm{m}) \\
\mathrm{n}= & \text { angka kekasaran Manning } \\
\mathrm{S}= & \text { kemiringan lahan }
\end{aligned}
$$

$T_{d}$ (Drain Flow Time) atau waktu aliran dimana air jatuh pada titik awal masuk sungai sampai ke outlet, dinyatakan dalam satuan jam.

$T_{d}$ dapat ditentukan dari kondisi pada saluran, jika aliran dimana parameter-parameter hidroliknya sulit ditentukan maka, $T_{d}$ dapat diperkirakan dengan menggunakan kecepatan aliran, dengan rumus (Suripin, 2002):

$$
T_{d}=\frac{L}{3600 v}(\mathrm{jam})
$$

dimana:

$$
\begin{aligned}
& L=\text { panjang sungai }(\mathrm{m}) \\
& v=\text { kecepatan aliran rata-rata }(\mathrm{m} / \mathrm{det}) .
\end{aligned}
$$

Dengan nilai $v$ dapat dihitung dengan rumus berikut :

$$
v=4,918(S)^{\frac{1}{2}}
$$

dimana:

$$
\begin{aligned}
& \mathrm{v}=\text { kecepatan aliran rata-rata }(\mathrm{m} / \mathrm{det}) \\
& \mathrm{S}=\text { Slope } \operatorname{sungai}(\mathrm{m} / \mathrm{m})
\end{aligned}
$$

\subsection{Koefisien Tampungan $\left(C_{s}\right)$}

Suatu areal DAS yang semakin luas akan berdampak terhadap semakin besarnya tampungan di sungai, dan berakibat juga terhadap besar debit banjir yang terjadi. Oleh karena itu, faktor koefisien tampungan diperhitungkan dalam metode rasional modifikasi. Koefisien tampungan dapat dirumuskan (Lewis et all., 1975):

$$
C_{s}=\frac{2 T_{c}}{2 T_{C}+T_{d}}
$$

dimana:

$T_{c}=$ waktu konsentrasi (jam)

$T_{d}=$ Drain Flow Time (jam)

\subsection{Koefisien Pengaliran $(C)$}

Koefisien pengaliran adalah suatu variabel yang didasarkan pada kondisi daerah pengaliran dan karakteristik hujan yang jatuh di daerah tersebut. Kondisi daerah pengaliran dan karakteristik hujan meliputi:

a. Keadaan hujan;

b. Luas dan bentuk daerah aliran;

c. Kemiringan daerah aliran dan kemiringan dasar sungai;

d. Daya infiltrasi dan perkolasi tanah;

e. Kelembaban tanah;

\section{f. Suhu udara, angin, dan evaporasi; dan}

g. Tata guna lahan.

Nilai koefisien pengaliran (C) adalah bilangan yang menunjukkan perbandingan antara besarnya air yang melimpas terhadap besarnya curah hujan. Angka koefisien pengaliran ini merupakan salah satu indikator untuk menentukan apakah suatu DAS tersebut telah mengalami gangguan fisik (Asdak, 2004).

Nilai koefisien pengaliran (C) yang besar menunjukkan jumlah limpasan permukaan yang terjadi pada lahan tersebut besar, dengan kata lain kondisi tata air dan tata guna lahan pada lahan tersebut rusak. Sebaliknya nilai koefisien pengaliran yang kecil menunjukkan jumlah limpasan permukaan yang terjadi pada lahan tersebut kecil, dengan kata lain jumlah air yang meresap ke dalam tanah dan memberikan kontribusi (recharge) air tanah besar.

Koefisien pengaliran seperti disajikan pada tabel berikut, didasarkan dengan suatu pertimbangan bahwa koefisien tersebut sangat tergantung pada faktor-faktor fisik. Harga koefisien pengaliran (C) untuk berbagai kondisi permukaan tanah dapat ditentukan sebagai berikut:

Tabel 2.Koefisien Pengaliran

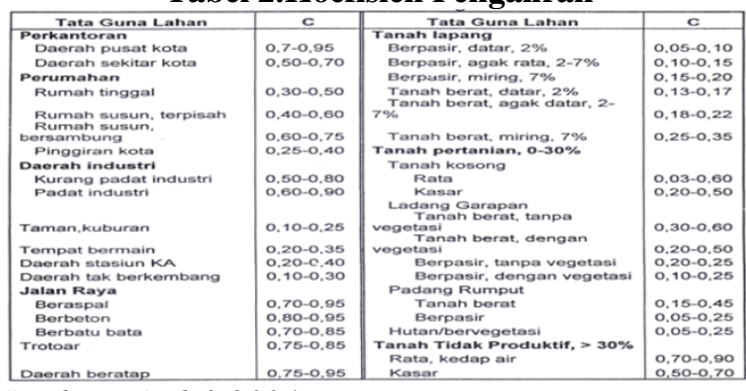

Sumber: Asdak,2004

\subsection{Analisa Debit Limpasan Permukaan Metode Rasional Modifikasi}

Debit limpasan permukaan adalah debit banjir terbesar tahunan dengan suatu kemungkinan terjadi yang tertentu, atau debit dengan suatu kemungkinan periode ulang tertentu. Untuk menentukan debit banjir rancangan dengan analisa frekuensi, diperlukan ketersediaan data debit tahunan pada lokasi yang dikaji, sedangkan permasalahan umum yang sering timbul di lapangan adalah tidak tersedianya data debit untuk keperluan tersebut.

Untuk itu, pendekatan terbaik adalah dengan menggunakan Metode Rasional Modifikasi, yang merupakan pengembangan dari metode Rasional, dimana waktu konsentrasi curah hujan yang terjadi lebih lama. Metode Rasional Modifikasi mempertimbangkan pengaruh tampungan dalam memperkirakan debit puncak limpasan. Rumus Metode Rasional Modifikasi dalam menentukan debit puncak, adalah sebagai berikut (Lewis et all.,1975):

$$
\mathrm{Q}=0,278 . \mathrm{C}_{\mathrm{s}} \cdot \mathrm{C} . \mathrm{I} . \mathrm{A}
$$




\section{JURNAL SIMETRIK VOL.8, NO.2, DESEMBER 2018}

dimana:

$$
\begin{aligned}
\mathrm{Q}= & \text { debit puncak dengan kala ulang } \\
& \text { tertentu }\left(\mathrm{m}^{3} / \mathrm{dt}\right) \\
0,278= & \text { faktor konversi } \\
C_{s}= & \text { koefisien tampungan } \\
C \quad= & \text { koefisien limpasan } \\
I \quad= & \text { intensitas hujan rata-rata dalam } \mathrm{t} \text { jam } \\
& (\text { mm/jam }) \\
A \quad= & \text { luas daerah pengaliran }\left(\mathrm{km}^{2}\right)
\end{aligned}
$$

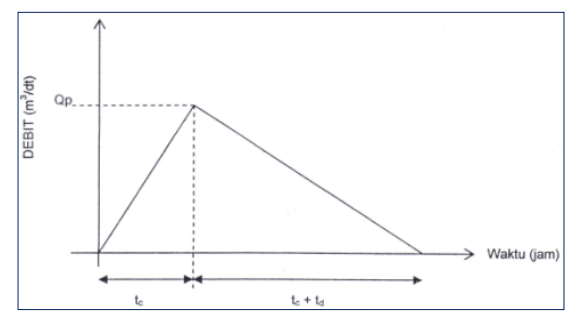

Sumber: Sitanala, Arsyad. 2012

Gambar 1. Hidrograf Rancangan Metode Rasional Modifikasi

\section{METODOLOGI}

\subsection{Jenis Penelitian}

Penelitian yang dilakukan adalah jenis penelitian deskriptif evaluatif (evaluative decriptional research), dengan tujuan memaparkan masalah dan identifikasi area sempadan sungai Wai Ruhu terdampak genangan oleh banjir rencana kala ulang 2, 5, 10 dan 50 tahun yang dihitung menggunakan metode Rasional Modifikasi.

\subsection{Lokasi Penelitian}

Lokasi penelitian dilakukan di DAS Wai Ruhu di Kota Ambon - Propinsi Maluku. Secara geografis, DAS Wai Ruhu terletak antara 3'39'44,18' - 3०41'39', LS dan $128^{\circ} 11^{\prime} 49,06^{\prime \prime}$ - 128 $18^{\circ}$ '46,47' BT (Gambar 3.):

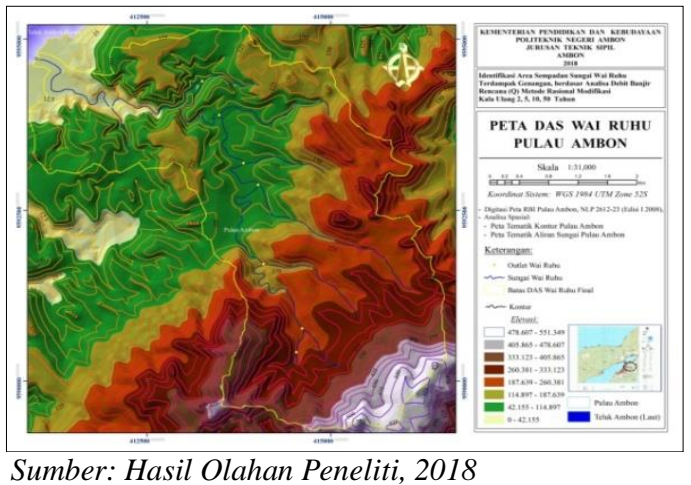

Gambar 2.Lokasi Studi (DAS Wai Ruhu)

\subsection{Jenis dan Sumber Data}

Jenis data yang dikumpulkan pada dasarnya terdiri dari data ruang dan data non ruang yang menggambarkan karakteristik DAS Wai Ruhu. Datadata yang dibutuhkan adalah:

1) Data curah hujan (sumber BMKG, Stasiun Meteorologi Pattimura Ambon)

2) Peta topografi (sumber BIG, digitasi peta RBI Pulau Ambon, NLP 2612-23, Edisi I Tahun 2008),
3) Peta penggunaan lahan eksisiting (survey dan digitasi peta sarana prasarana desa, produksi BAPPEKOT Kota Ambon, Tahun 2008),

4) Peta Daerah Aliran Sungai (sumber hasil digitasi Peta RBI)

\subsection{Metode Analisa Data}

Penelitian ini dilakukan dengan beberapa tahapan yakni:

1) Menghitung Intensitas hujan dengan Metode Mononobe dari data curah hujan tahun 2003 2013 yang didapat dari BMKG Stasiun Meteorologi Pattimura Ambon.

2) Membuat peta tematik DAS Wai Ruhu dari olahan peta RBI Pulau Ambon, NLP 2612-23, Edisi I Tahun 2008

3) Menganalisis penggunaan lahan yang ada dan membuat peta tematik guna lahan dari olahan peta DAS Wai Ruhu dan peta saran prasarana produksi BAPPEKOT Kota Ambon, tahun 2008.

4) Menghitung debit banjir limpasan dengan metode Rational Modifikasi pada DAS Wai Ruhu dari hasil olahan peta tematik guna lahan dan data intensitas hujan.

5) Membuat peta tematik limpasan pada sempadan sepanjang aliran sungai di DAS Wai Ruhu.

\section{HASIL DAN PEMBAHASAN}

\subsection{Hasil Penelitian}

A. Curah Hujan

Dari data curah hujan 2003 - 2013 rerata daerah, digunakan parameter statistik untuk menghitung curah hujan rencana sebaran normal untuk periode ulang 2 , 5, 10 dan 50 tahun, (Tabel 3.)

Tabel 3.Perhitungan Parameter Statistik Curah

\begin{tabular}{|c|c|c|c|c|c|c|c|c|c|c|c|}
\hline & & & Event & 位 & the & 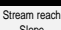 & & 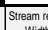 & & 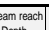 & 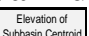 \\
\hline & \begin{tabular}{|l} 
Sibobasin \\
\end{tabular} & tering & 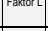 & 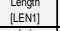 & $\begin{array}{l}\text { soler } \\
\text { [s:010 }\end{array}$ & 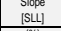 & Fantrots & (wiol & & Depen & \\
\hline & & ${ }^{2669923}$ & & $=\frac{[1](1) 2923}{2,6923}$ & $\frac{1801}{1251}$ & $\frac{8109}{2439}$ & & & & 0.12 & \\
\hline & $\begin{array}{l}3691 \\
61670\end{array}$ & 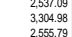 & & 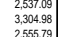 & $\begin{array}{l}2.907 \\
1974 \\
10.24\end{array}$ & 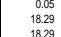 & $\begin{array}{l}0.1 \\
3.1 .0\end{array}$ & & & $\begin{array}{l}0.99 \\
0.16 \\
0.16\end{array}$ & 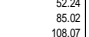 \\
\hline & 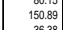 & 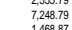 & \begin{tabular}{|l}
322499 \\
32679
\end{tabular} & $\begin{array}{l}7.24797 \\
1.78698\end{array}$ & $\begin{array}{r}23000 \\
823\end{array}$ & $\begin{array}{l}152424 \\
155029\end{array}$ & $\begin{array}{l}3.1 \\
114\end{array}$ & & & . & $\begin{array}{l}20.08 \\
21080\end{array}$ \\
\hline & & 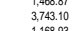 & & 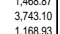 & 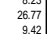 & $\begin{array}{l}0.06 \\
0.056 \\
0.098\end{array}$ & $\begin{array}{l}0.1 \\
0.14\end{array}$ & & & $\begin{array}{l}0.14 \\
0.14 \\
0.09\end{array}$ & 15.0. \\
\hline & $\begin{array}{l}90.77 \\
90757\end{array}$ & 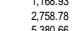 & & 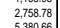 & $\begin{array}{c}14.111 \\
20.11\end{array}$ & $\begin{array}{l}2.3939 \\
4.354\end{array}$ & 3.1 & & & (3) & $\begin{array}{r}88.95 \\
20610\end{array}$ \\
\hline & 20.04 & 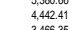 & & 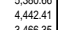 & 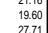 & $\begin{array}{l}1824 \\
01829 \\
0.05\end{array}$ & $\begin{array}{l}3.1 \\
0.1\end{array}$ & & & $\begin{array}{l}0.16 \\
0.16 \\
0.12\end{array}$ & 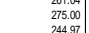 \\
\hline & $\begin{array}{c}1030.55 \\
9.40\end{array}$ & $\begin{array}{l}2.790 .56 \\
73936\end{array}$ & $\mid \begin{array}{l}12684 \\
32.64\end{array}$ & $\begin{array}{l}2770.5656 \\
793937\end{array}$ & $\begin{array}{l}2.061 \\
10.91\end{array}$ & $\begin{array}{l}15.24 \\
18.29\end{array}$ & . & & & $\begin{array}{l}0.13 \\
0.05\end{array}$ & \\
\hline 11 & 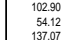 & 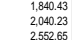 & 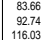 & 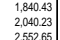 & 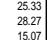 & $\begin{array}{l}\text { o.05 } \\
\text { o. } \\
2435\end{array}$ & 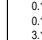 & & & $\begin{array}{l}0.13 \\
0.10 \\
0.14\end{array}$ & \\
\hline
\end{tabular}
Hujan Rencana Sebaran Normal

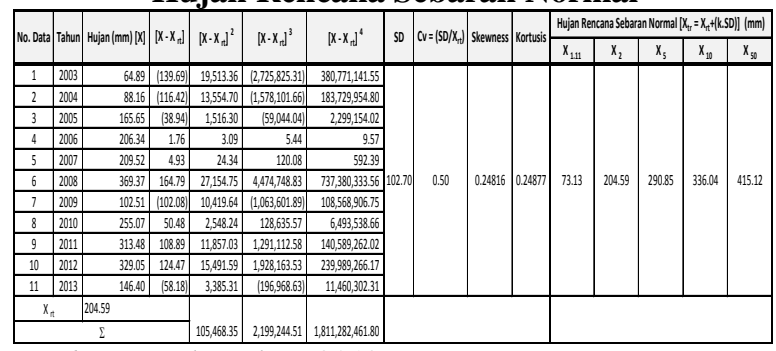

Sumber :Hasil Analisa, 2018

B. Data atribut sub-Basin dan sungai dari hasil pembuatan batas DAS dengan menggunakan $D E M$

Tabel 4.Data atribut SUB BASIN - DAS Wai Ruhu

Sumber :Hasil Analisa Spasial ArcView GIS 3.3 \& ArcGIS 9.3, 2018 


\section{JURNAL SIMETRIK VOL.8, NO.2, DESEMBER 2018}

Tabel 5. Data atribut SUNGAI- DAS Wai Ruhu

\begin{tabular}{|c|c|c|c|c|c|c|}
\hline \multirow[t]{2}{*}{ Subbasin } & $\begin{array}{c}\text { Luas } \\
\text { Subbasin }\end{array}$ & $\begin{array}{c}\text { Luas Area } \\
\text { Cakupan } \\
\text { [AREAC] }\end{array}$ & $\begin{array}{l}\text { Panjang } \\
\text { Sungai } \\
\text { [LEN2] }\end{array}$ & $\left.\begin{array}{c}\text { Slope } \\
\text { Sungai } \\
{[\text { SLO2] }}\end{array}\right]$ & \begin{tabular}{|c|} 
Elevasi Minimum \\
Sungai \\
[MINEL]
\end{tabular} & $\begin{array}{c}\text { Elevasi Maksimum } \\
\text { Sungai } \\
\text { [MAXEL] }\end{array}$ \\
\hline & (ha) & (ha) & (m) & (\%) & (m) & (m) \\
\hline$\overline{1}$ & 89.85 & 89.86 & $1,033.93$ & 7.27 & 50.00 & 125.00 \\
\hline 2 & 36.91 & 1274.34 & $1,872.10$ & 1.34 & 50.00 & 75.00 \\
\hline 3 & 157.09 & 1521.29 & $\begin{array}{l}1,985.25 \\
\end{array}$ & 1.89 & 12.50 & 50.00 \\
\hline 4 & 80.15 & 80.15 & 915.88 & 6.84 & 12.50 & 75.00 \\
\hline 5 & 150.89 & 150.90 & $2,240.76$ & 3.68 & 75.00 & 157.38 \\
\hline 6 & 36.38 & 1086.53 & $1,164.14$ & 0.10 & 75.00 & 75.00 \\
\hline 7 & 113.32 & 113.32 & $1,409.81$ & 3.55 & 75.00 & 125.00 \\
\hline 8 & 37.88 & 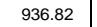 & 924.40 & 0.10 & 75.00 & 75.00 \\
\hline 9 & 90.77 & 622.00 & $2,361.48$ & 2.12 & 75.00 & 125.00 \\
\hline 10 & 276.94 & 276.94 & 7.26 & 4.80 & 75.00 & 250.00 \\
\hline 11 & 17 & 17 & $2,127.88$ & 7.07 & 125.00 & 275.00 \\
\hline 12 & 90.30 & 359.80 & $2,101.54$ & 4.76 & 125.00 & 225.00 \\
\hline 13 & 103.05 & $\begin{array}{l}103.05 \\
\end{array}$ & $1,142.00$ & 7.85 & 225.00 & $\begin{array}{l}314.39 \\
\end{array}$ \\
\hline 14 & 9.40 & 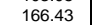 & 466.23 & 5.37 & 225.00 & 250.00 \\
\hline 15 & 102.90 & 102 & 325.26 & 7.71 & 250.00 & 275.00 \\
\hline 16 & 54.12 & & 191.91 & 0.10 & 250.00 & 250.00 \\
\hline 17 & 137.07 & 1728.57 & $2,064.92$ & 0.58 & 0.55 & 12.50 \\
\hline & & & & & & \\
\hline
\end{tabular}

Sumber :Hasil Analisa Spasial ArcView GIS $3.3 \&$ ArcGIS 9.3, 2018 3.):

Berikut peta Sub Basin DAS Wai Ruhu (Gambar

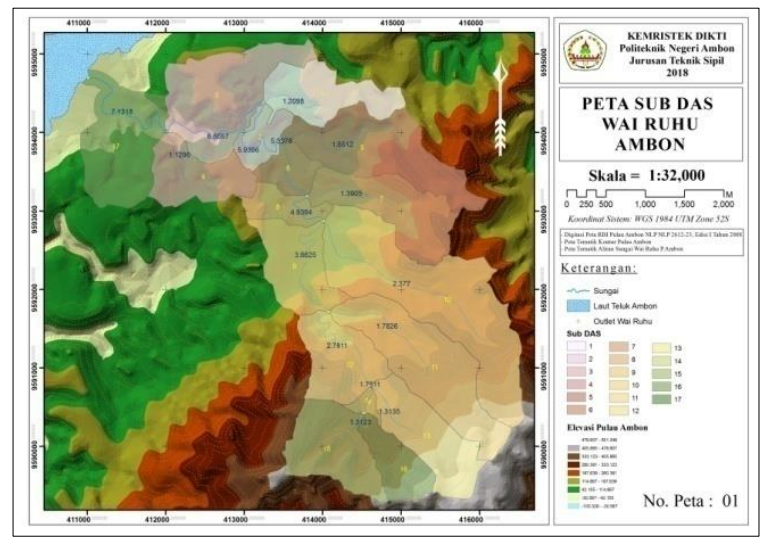

Sumber : Hasil Olahan, 2018

Gambar 3. Peta Sub Basin DAS Wai Ruhu

C. Koefisien Tampungan $\left(C_{s}\right)$

Nilai koefisien tampungan didapat setelah terlebih dahulu kita mengestimasi waktu konsentrasi $\left(\mathrm{T}_{\mathrm{c}}\right)$ yaitu waktu perjalanan yang diperlukan oleh air dari tempat paling jauh (hulu DAS) sampai titik pengamatan aliran air (outlet). Berikut adalah hasil perhitungannya (Tabel 6.)

Tabel 6. Hasil perhitungan koefisien tampungan

\begin{tabular}{|c|c|c|c|c|c|c|c|c|c|c|}
\hline \multicolumn{11}{|c|}{$(C s)$} \\
\hline & 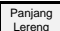 & exintangan & 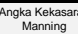 & $\begin{array}{l}\text { overand } \\
\text { fowow Time }\end{array}$ & $\begin{array}{l}\text { Panialang } \\
\text { sunnaga }\end{array}$ & $\begin{array}{l}\text { Slope } \\
\text { sungail }\end{array}$ & $\begin{array}{c}\text { Kocepoatan } \\
\text { Aliran }\end{array}$ & $\begin{array}{l}\text { Dorain } \\
\text { Hot Wrime }\end{array}$ & $\begin{array}{l}\text { Waktu } \\
\text { Konsentras }\end{array}$ & 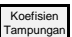 \\
\hline SuL:Sub DAS & $\begin{array}{l}(4) \\
(m) \\
(m)\end{array}$ & $|s|$ & {$[n]$} & $\frac{\left[\mathrm{T}_{\mathrm{d}}\right]}{\mathrm{g}(\mathrm{mam})}$ & 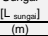 & [s seraul] & $\frac{[(1)]}{(m, d e r)}$ & 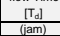 & $\frac{\left[T_{d}\right]}{(\sigma a m)}$ & {$\left[\mathrm{C}_{\mathrm{B}}\right]$} \\
\hline & 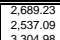 & 0.25 & $\begin{array}{l}0.025 \\
.0 .25\end{array}$ & $\begin{array}{l}4.666 \\
.677\end{array}$ & $\begin{array}{l}1.877210 \\
0.525\end{array}$ & 然. & $\begin{array}{l}1.1 .13 \\
0.49 \\
.05\end{array}$ & $\begin{array}{ll}0.20 \\
1.07\end{array}$ & $\begin{array}{ll}7.78 \\
5.69\end{array}$ & 0.91 \\
\hline & $\begin{array}{l}2.555 .79 \\
2.559 .79\end{array}$ & $\begin{array}{l}0.16 \\
0.16 \\
0.23\end{array}$ & $\begin{array}{l}0.025 \\
0.025 \\
0.025\end{array}$ & $\begin{array}{l}0.778 \\
51.778 \\
13.727\end{array}$ & 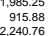 & $\begin{array}{l}0.02 \\
0.07 \\
0.04\end{array}$ & 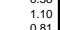 & $\begin{array}{l}0.23 \\
0.77 \\
0.77\end{array}$ & $\begin{array}{l}6.01 \\
61.55 \\
14.55\end{array}$ & {$\left[\begin{array}{l}0.986 \\
0.97\end{array}\right]$} \\
\hline & $\begin{array}{l}\quad \begin{array}{l}1,4668.87 \\
3.743 .10\end{array} \\
3\end{array}$ & $\begin{array}{l}0.08 \\
0.27\end{array}$ & $\begin{array}{l}0.025 \\
0.025\end{array}$ & 6.591 & $\begin{array}{l}1,164.44 \\
1,4098.81\end{array}$ & $\begin{array}{l}0.00 \\
.0 .04\end{array}$ & $\begin{array}{l}0.13 \\
0.79\end{array}$ & $\begin{array}{l}2.44 \\
0.50\end{array}$ & $\begin{array}{l}7.70 \\
7.09\end{array}$ & \begin{tabular}{l|l}
0.055 \\
0.97
\end{tabular} \\
\hline 9 & $\begin{array}{l}2,7,255.78 \\
2,758.78\end{array}$ & . 0.14 & $\begin{array}{l}0.025 \\
0.025\end{array}$ & $\begin{array}{l}6.662 \\
0.6657\end{array}$ & 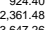 & $\begin{array}{l}0.02 \\
0.02\end{array}$ & 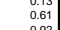 & $\begin{array}{l}1.93 \\
1.07\end{array}$ & $\begin{array}{l}5.747 \\
7.77\end{array}$ & $\begin{array}{l}0.85 \\
0.94 \\
0.969\end{array}$ \\
\hline $\begin{array}{l}11 \\
12\end{array}$ & $\begin{array}{l}4.442 .21 \\
3.466 .35\end{array}$ & $\begin{array}{l}0.20 \\
0.28\end{array}$ & $\begin{array}{l}0.025 \\
0.025 \\
0\end{array}$ & $\begin{array}{l}9.1 .144 \\
5.999\end{array}$ & $\begin{array}{l}\text { 2.127.78 } \\
\text { 2.121.154 }\end{array}$ & $\begin{array}{l}0.07 \\
0.05\end{array}$ & $\begin{array}{l}\text { t.1.2. } \\
0.922\end{array}$ & $\begin{array}{l}0.53 \\
0.64\end{array}$ & $\begin{array}{l}9.67 \\
6.64\end{array}$ & $\begin{array}{l}0.97 \\
0.95\end{array}$ \\
\hline & & $\begin{array}{l}0.21 \\
0.17 \\
0.25\end{array}$ & $\begin{array}{l}0.025 \\
0.025 \\
0.255\end{array}$ & $\begin{array}{l}1.638 \\
3_{3332}\end{array}$ & 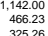 & $\begin{array}{l}0.008 \\
.008\end{array}$ & $\begin{array}{l}1.1 .18 \\
0.97 \\
.197\end{array}$ & $\begin{array}{l}0.07 \\
0.017 \\
0.08\end{array}$ & $\begin{array}{l}5.87 \\
1.777 \\
3.41\end{array}$ & $\begin{array}{l}0.98 \\
0.96 \\
0.969\end{array}$ \\
\hline 16 & & $\begin{array}{l}0.28 \\
0.15\end{array}$ & $\begin{array}{l}0.025 \\
0.025 \\
0\end{array}$ & 34 & $\begin{array}{l}\text { 1919.91 } \\
\text { 2.064.92 }\end{array}$ & 0.00 & 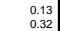 & 0.40 & $\begin{array}{l}3.90 \\
7.79 \\
\end{array}$ & 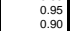 \\
\hline
\end{tabular}

Sumber :Hasil Analisa, 2018

D. Intensitas Hujan (I)

Setelah menentukan curah hujan sebaran normal dan waktu konsentrasi $\left(\mathrm{T}_{\mathrm{c}}\right)$, maka penentuan besaran intensitas hujan (I) dapat dilakukan.Berikut hasil perhitungan intensitas hujan dengan metode
Mononobe untuk kala ulang 2, 5, 10, dan 50 tahun (Tabel 7.)

Tabel 7. Hasil perhitungan intensitas hujan (I)

\begin{tabular}{|c|c|c|c|c|c|c|c|c|c|}
\hline \multirow{2}{*}{ Sub-sub DAS } & Waktu & \multirow{2}{*}{$\begin{array}{c}\mathrm{R}_{24} \\
\text { (2 Tahun) }\end{array}$} & \multirow{2}{*}{ 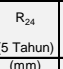 } & \multirow{2}{*}{\begin{tabular}{|c|}
$R_{24}$ \\
$(10$ Tahun)
\end{tabular}} & \multirow{2}{*}{$\begin{array}{c}\mathrm{R}_{24} \\
\text { (50 Tahur) }\end{array}$} & \multirow{2}{*}{ 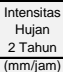 } & \multirow{2}{*}{ 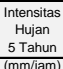 } & \multirow{2}{*}{ 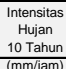 } & \multirow{2}{*}{\begin{tabular}{|l|}
$\begin{array}{l}\text { Intensitas } \\
\text { Hulain } \\
50 \text { Tahun }\end{array}$ \\
50
\end{tabular}} \\
\hline & 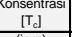 & & & & & & & & \\
\hline & & $\frac{(m) m}{204.59}$ & & $\frac{(\mathrm{mm})}{336.04}$ & & & & & \\
\hline & $\begin{array}{l}5.69 \\
.79\end{array}$ & $\begin{array}{l}204.59 \\
204.59\end{array}$ & 290.85 & $\begin{array}{l}336.04 \\
3364\end{array}$ & & $\begin{array}{l}2.2 .26 \\
226\end{array}$ & 31.64 & 36.56 & 45.16 \\
\hline & $\begin{array}{ll}6.01 \\
6\end{array}$ & 204095 & & $\begin{array}{l}336.04 \\
336.04\end{array}$ & & $\begin{array}{l}18.14 \\
21.46\end{array}$ & $\begin{array}{l}25.79 \\
30.50\end{array}$ & & \\
\hline & 4.55 & 204. & & & & 30 & 16.92 & 9.55 & 15 \\
\hline & 7.09 & 204.59 & & $\begin{array}{l}336.04 \\
336.04\end{array}$ & & & $\begin{array}{l}29 \\
33\end{array}$ & 58 & \\
\hline & 541 & & & 336 & 415 & & & & \\
\hline & 11.76 & 204.59 & $\begin{aligned} 290 \\
2090\end{aligned}$ & $\begin{array}{l}3566.04 \\
336.04\end{array}$ & 45.12 & 13.72 & 19. & 22.53 & \\
\hline & & & & & & & 22.21 & & \\
\hline & 5.87 & 204.59 & & & & 21.80 & $\begin{array}{r}2.5095 \\
309\end{array}$ & 25890 & \\
\hline & 1.777 & ${ }^{9}$ & & & & & 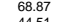 & 7 & 88.30 \\
\hline 17 & $\begin{array}{l}3.90 \\
779\end{array}$ & $\begin{array}{l}204.59 \\
20459\end{array}$ & $\begin{array}{l}290.85 \\
290.85\end{array}$ & $\begin{array}{l}3364.04 \\
33604\end{array}$ & $\begin{array}{l}\text { 415112 } \\
41512\end{array}$ & $\begin{array}{l}2.8 .64 \\
1805 \\
1805\end{array}$ & 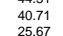 & 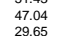 & 3663 \\
\hline
\end{tabular}

Sumber :Hasil Analisa. 2018

\section{E. Guna Lahan}

Berikut peta guna lahan hasil digitasi, ditambahkan atribut koefisien limpasan (C). (Gambar 4.)

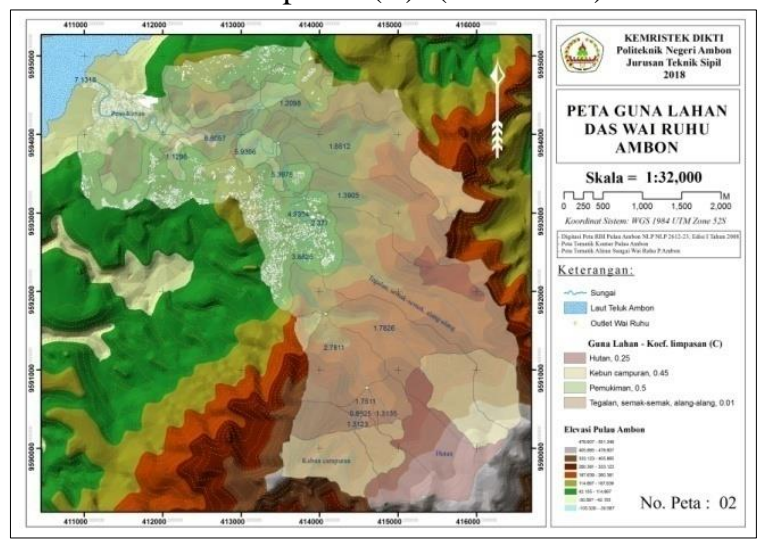

Sumber : Hasil Olahan, 2018

\section{Gambar 4. Peta Guna Lahan Wai Ruhu}

F. Debit Limpasan Permukaan (Q) dan kumulatif banjir rencana ( $\mathrm{Q})$ Metode Rasional Modifikasi.

Berdasarkan parameter koefisien tampungan $\left(C_{S}\right)$, koefisien limpasan $(C)$, intensitas hujan rata-rata $(I)$, dan luas daerah pengaliran (A) maka dapat diestimasi debit limpasan permukaan $(Q)$ untuk kala ulang hujan 2, 5, 10 dan 50 tahun (Tabel 8):

Tabel 8. Hasil perhitungan $Q$ untuk periode ulang 2, 5, 10 dan 50 tahun

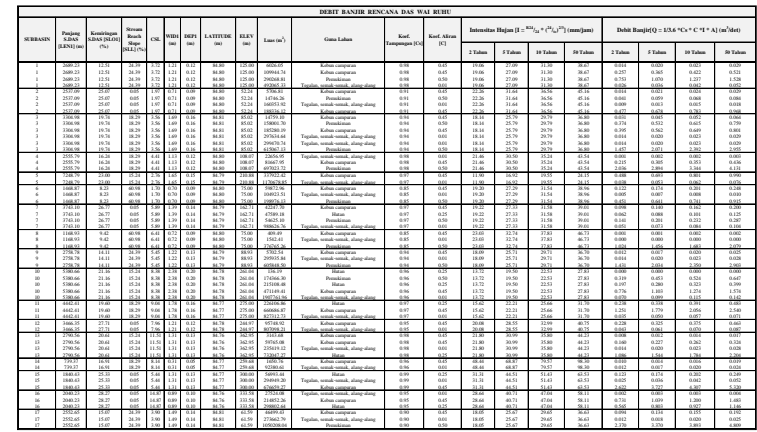

Sumber :Hasil Analisa, 2018

Hasil debit limpasan permukaan/banjir rencana (Q) setiap aliran sungai pada ketujuh belas anak 


\section{JURNAL SIMETRIK VOL.8, NO.2, DESEMBER 2018}

sungai (subbasin) yangdiestimasi seperti yang ditampilkan pada tabel 8, kemudian diakumulasi untuk mendapatkan debit maksimum dari urutan elevasi tertinggi sampai terendah (Tabel 9).

Tabel 9. Kumulatif $Q$ Subbasin kala ulang 2, 5, 10 dan 50 tahun

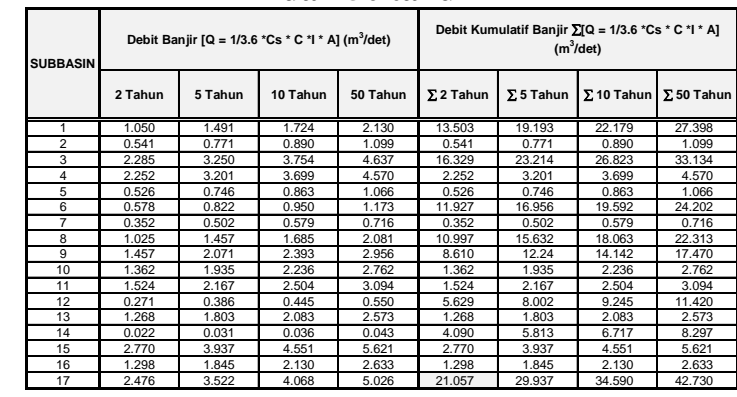

Sumber :Hasil Analisa, 2018

G. Area Terdampak Limpasan.

Hasil penentuan selisih luas penampang basah akibat debit limpasan kumulatif akan menghasilkan luas area genangan, dilengkapi dengan parameter penampang sungai dan kemiringan lereng di atas bibir sungai (muka air sungai normal), maka dapat diproyeksikan lebar dan ketinggian genangan di sempadan sungai. Analisanya dapat dilakukan dengan mengidealisasi irisan penampang melintang sungai dari data olahan $D E M$ ke gambar CAD dan luas penampang minimum dan maksimum dikalkulasi sebelum mencari tinggi genangan/ limpasan dengan cara mensinkronkan area genangan/ limpasan masing-masing anak sungai untuk setiap periode ulang, dengan cara interpolasi antara selisih luas penampang basah dengan pasangan tinggi genangan untuk masing-masing nilai, yaitu penampang basah akibat limpasan minimum, penampang basah akibat limpasan periode 2, 5, 10, 50 tahun, dan area penampang basah akibat limpasan maksimum, yang hasilnya sebagai berikut: (Tabel 10.)

Tabel 10.Hasil interpolasi korelasi luas penampang basah akibat limpasan dengan tinggi genangan akibat limpasan.

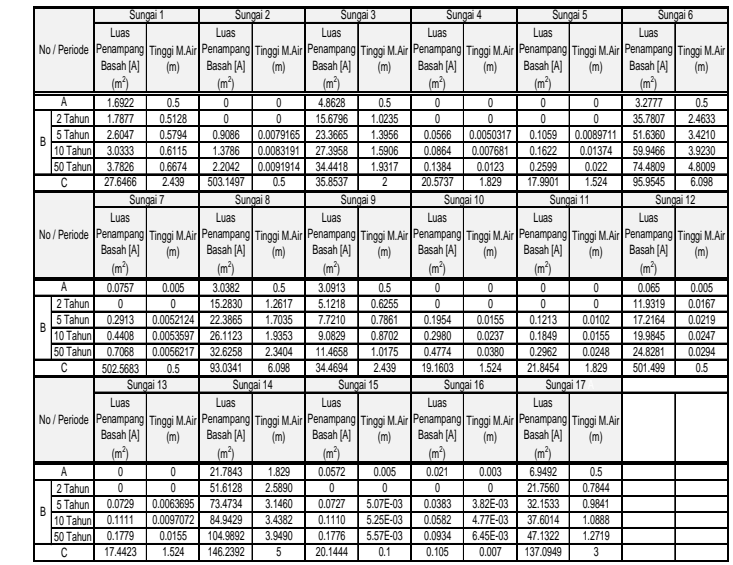

Sumber :Hasil Analisa, 2018

Untuk lebih jelas tentang area sempadan terdampak debit banjir limpasan, bisa direkapitulasi sebagai berikut (Tabel 11.):
Tabel 11. Rekapitulasi area terdampak genangan akibat debit banjir limpasan periode ulang 2, 5, 10 dan 50 tahun

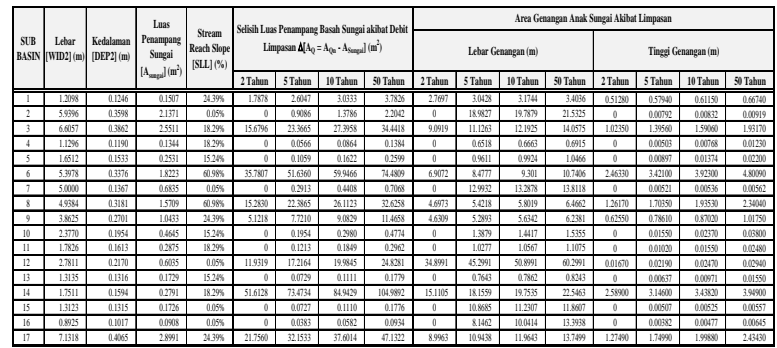

Sumber :Hasil Analisa, 2018

\subsection{Pembahasan}

Dari tabel rekapitulasi area terdampak genangan (Tabel 11), tergambar bahwa sempadan pada anak sungai yang terdampak limpasan terbesar, terjadi pada anak sungai ke-12 dengan lebar genangan akibat limpasan mencapai 60,2991 m dari bibir sungai, dan tinggi genangan akibat limpasan terbesar adalah anak sungai ke-6 dengan tinggi genangan mencapai 4,8009 $\mathrm{m}$ dari muka air normal. Keduanya dicapai pada hujan rencana dengan periode ulang 50 tahun. Hal ini tergambar pada peta sempadan Sungai Wai Ruhu terdampak limpasan / genangan dan grafik untuk setiap periode banjir rencana (Gambar 5 sampai 9):

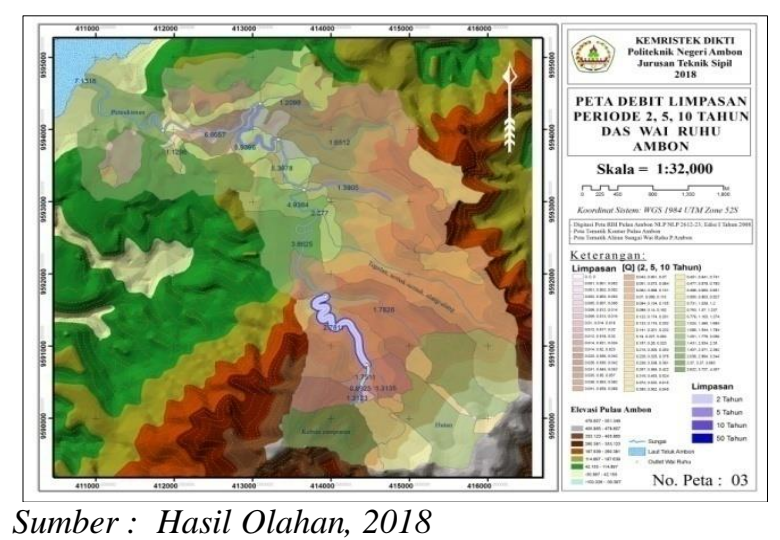

Gambar 5. Peta Limpasan Wai Ruhu Periode 2, 5 \& 10 Tahun

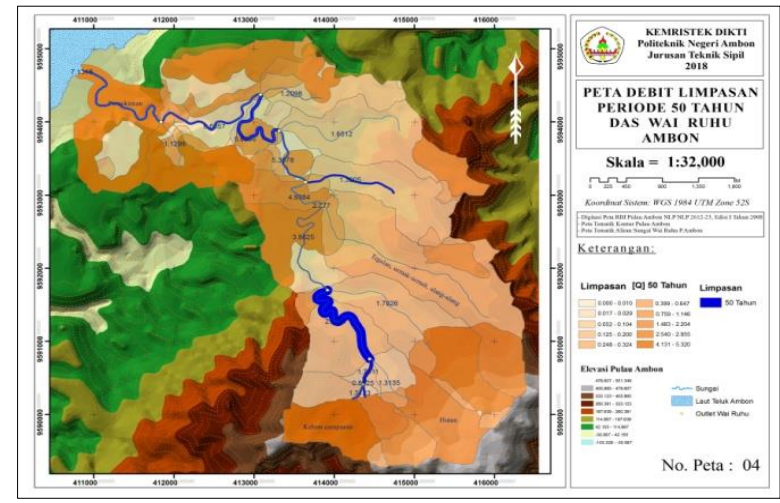

Sumber: Hasil Olahan, 2018

Gambar 6. Peta Limpasan Wai Ruhu Periode 50 Tahun 


\section{JURNAL SIMETRIK VOL.8, NO.2, DESEMBER 2018}

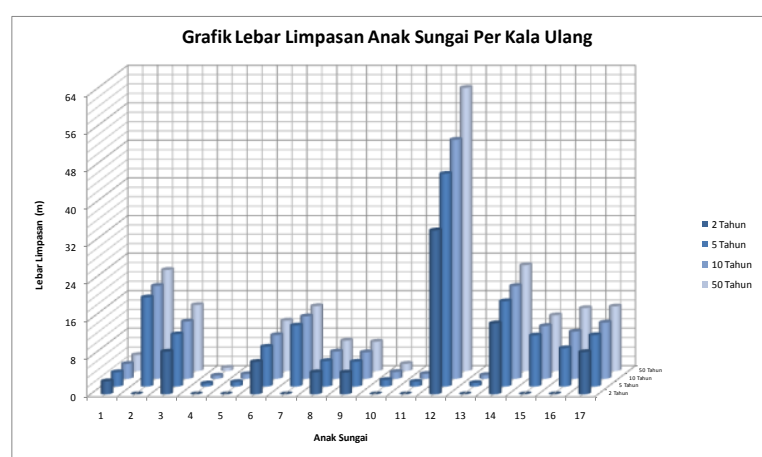

Sumber : Hasil Olahan, 2018

\section{Gambar 7. Grafik lebar limpasan anak Sungai} Wai Ruhu per kala ulang banjir rencana

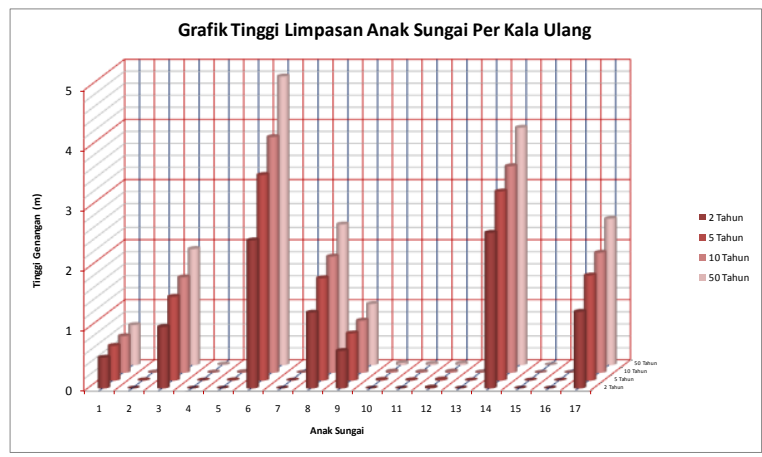

Sumber : Hasil Olahan, 2018

\section{Gambar 8. Grafik tinggi genangan anak Sungai Wai Ruhu per kala ulang banjir rencana}

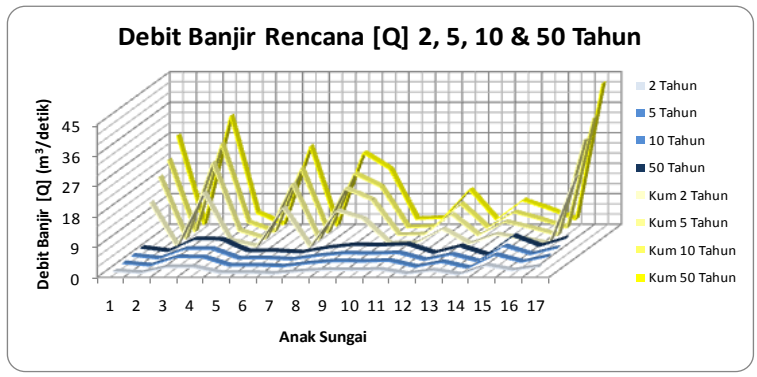

Sumber : Hasil Olahan, 2018

Gambar 9. Grafik debit banjir rencana [Q] periode 2, 5, 10 dan 50 tahun Sungai Wai Ruhu

\section{PENUTUP}

\subsection{Kesimpulan}

Kesimpulandari hasil penelitian ini:

1) Debit kumulatif banjir rencana dengan nilai terendah terjadi pada anak sungai pada sub DAS ke-7, berlaku untuk periode ulang $2 ; 5 ; 10$ dan 50 tahun yaitu masing-masing sebesar 0,352 ; 0,$502 ; 0,579 ; 0,716 \mathrm{~m}^{3} /$ det. Sedangkan debit kumulatif banjir rencana dengan nilai tertinggi terjadi pada anak sungai pada sub DAS ke-17, dan berlaku untuk periode ulang $2 ; 5 ; 10$ dan 50 tahun yaitu masing-masing sebesar 21,057 ; 29,$937 ; 34,590 ; 42,730 \mathrm{~m}^{3} /$ det.
2) Limpasan pada masing-masing anak sungai di DAS Wai Ruhu dengan tinggi minimum (tidak ada limpasan), terjadi di masing-masing anak sungai pada sub DAS ke-2, 4, 5, 7, 10, 11, 13, 15 dan ke-16 untuk periode ulang 2 tahun karena merupakan anak sungai yang mensuplai debit banjir awal ke anak sungai lainnya, sedangkan tinggi genangan maksimum terjadi pada anak sungai di sub DAS ke-6 yaitu sebesar 4,8009 m dari muka air sungai normal. Lebar minimum limpasan (0 m), terjadi pada sub DAS yang sama dengan tinggi minimum, sedangkan lebar maksimum limpasan terjadi pada anak sungai di sub DAS ke-12 yaitu selebar 60,2991 m dari tepi sungai.

\subsection{Saran}

1) Lahan di sempadan sungai yang rawan bencana banjir akibat limpasan dan relatif berbahaya sebagai kawasan pemukiman dan direkomendasikan untuk dilakukan tindakan pencegahan dan penanggulanagn bencana banjir adalah pada anak sungai di SUB DAS ke-1, 3, 6, 8, 9, 14 dan ke-17 karena mengalami tinggi genangan antara 0,5128 - 4,8009 m untuk semua periode ulang hujan rencana.

2) Sub DAS yang sempadan sungainya telah berfungsi sebagai kawasan pemukiman dan rawan terhadap limpasan akibat banjir adalah pada sub DAS ke-3, 6, 7 - 10 dan ke-17 sehingga perlu mendapat perhatian dari semua pihak terkait dalam penanggulangan bencana banjir.

\section{DAFTAR PUSTAKA}

Asdak, C. 2004. Hidrologi dan Pengelolaan Daerah Aliran Sungai.Gadjah Mada University Press. Yogyakarta.

Badan Meteorologi Klimatologi dan Geofisika.2013. Stasiun Meteorologi Pattimura Ambon.

Badan Informasi Geospasial. 2008.

Diah Ayu Kusumadewi, Ludfi Djakfar, Moh. Bisri. 2012. Arahan spasial teknologi drainase untuk mereduksi genangan di Sub Daerah Aliran Sungai Watu bagian hilir. Jurnal Teknik Pengairan, Volume 3, Nomor 2, Desember 2012, $(258$ - 276)

Harto, Sri. 1993. Analisis Hidrologi. Gramedia Pustaka Utama. Jakarta

http://ambonkota.bps.go.id/tabel-23-penduduk.html http://www.radarambon.co/read-20120803233042-8sungai-di-ambon-kritis-banjir-bisa-terulang-berita_utama

Nugroho, $\bar{H}$. 2012. Aplikasi Hidrologi. Jogja Mediautama. Malang.

Pattiselanno, S.R.R, 2014. Penanganan Kawasan Bencana Longsor DAS Wai Ruhu, Jurnal REKAYASA SIPIL/Vol.8, No.1-2014 ISSN 19785658/ Fakultas Teknik Universitas Brawijaya. Malang.

Prahasta, E. 2004.Sistem Informasi Geografis: Tutorial Arc View. Penerbit Informatika. Bandung. 


\section{JURNAL SIMETRIK VOL.8, NO.2, DESEMBER 2018}

Ronaldo Toar Palar, L. Kawet, E.M. Wuisan, H. Tangkudung. 2013. Studi Perbandingan Antara Hidrograf SCS (Soil Conservation Service) dan Metode Rasional pada DAS Tikala. Jurnal Sipil Statik Vol.1 No.3, Februari 2013 (171176)

Siaran Pers Nomor: S.596/PIK-1/2008, 2008: www.dephut.go.id

Sitanala, Arsyad. 2012. Konservasi Tanah dan Air, Edisi Kedua.IPB Press. Bogor.

Suripin.2002. Pelestarian Sumber Daya Tanah dan Air. Penerbit Andi. Yogyakarta 